\title{
Representasi Matematis Siswa Bergaya Kognitif Visualizer- Verbalizer dalam Menyelesaikan Soal Matematika TIMSS
}

\author{
M. Syahid ${ }^{1 *}$, Kurnia Noviartati ${ }^{2}$ \\ ${ }^{1,2}$ STKIP Al Hikmah Surabaya, Surabaya, Jawa Timur 60233, Indonesia \\ Pengiriman: 27 Januari 2019; Diterima: 23 April 2019; Publikasi: 30 April 2019 \\ DOI: https://doi.org/10.31629/jg.v4i1.934
}

\begin{abstract}
Abstrak
Penelitian deskriptif kualitatif ini bertujuan untuk mendeskripsikan representasi matematis siswa bergaya kognitif visualizer-verbalizer dalam menyelesaikan soal TIMSS. Subjek pada penelitian ini terdiri dari 4 siswa dimana 2 diantaranya merupakan siswa bergaya kognitif visualizer rendah dan tinggi, dan 2 lainnya merupakan siswa bergaya kognitif verbalizer rendah dan tinggi. Instrumen pada penelitian ini adalah peneliti sendiri dan dibantu dengan lembar angket gaya kognitif, lembar tes soal TIMSS, dan pedoman wawancara. Teknik pengumpulan data yang digunakan yaitu berupa tes gaya kognitif, tes soal TIMSS, dan wawancara siswa. Adapun teknik analisis data yang digunakan yaitu reduksi data, penyajian data, dan penarikan kesimpulan. Hasil peneltian ini menunjukkan bahwa representasi matematis bergaya kognitif visualizer mampu mengerjakan soal dalam bentuk gambar atau ilustrasi dengan baik melalui tahapan-tahapan yang telah ditetapkan oleh peneliti, yaitu; ketertarikan pada soal sesuai gaya kognitifnya, memahami soal lebih ketimbang siswa yang bergaya konitif verbalizer, menggunakan cara penyelesaian lebih baik juga hingga mendekati kesempurnaan pada jawabannya. Representasi matematis siswa bergaya kognitif verbalizer mampu mengerjakan soal yang disajikan dengan soal cerita atau narasi, lebih mudah memahami serta mampu menguraikan dengan baik serta mampu merepresentasikan dalam bahasa matematika.
\end{abstract}

Kata kunci: representasi matematis; gaya kognitif visualizer-verbalizer; TIMSS.

\begin{abstract}
This study aims to describe students' mathematical representations in a cognitive style of visualizer in solving TIMSS problems. This research is a qualitative descriptive study. The research subject consisted of 4 students where 2 of them were students with low and high visualizer cognitive style, and 2 others were students with low and high verbalizer cognitive styles. The instruments in this study were the researchers themselves and assisted with cognitive style questionnaire sheets, TIMSS test sheets, and interview guidelines. Data collection techniques used were in test form of cognitive stylsts, TIMSS test questions, and student interviews. The technical data analysis used were data reduction, data presentation, and drawing conclusions. The results of this study showed that mathematical representations of visualizer cognitive style were able to work on the questions in the form of images or illustrations well through the stages set by the researcher, namely; the interest in the question according to its cognitive style, understanding the problem more than the student who has a positive verbalizer style, uses a better solution to approach the perfection of the answer. Students' mathematical representations in the verbalizer cognitive style were able to work on questions presented with story or narrative questions that were easier to understand and were able to describe well and to do representing within mathematical languages.
\end{abstract}

Keywords: mathematical representation; visualizer-verbalizer cognitive style; TIMSS

*Penulis Korespondensi

Email Address: syahid07.math@gmail.com

Handphone : +6283852575505 
JURNAL GANTANG. April 2019; IV(1): 49 - 59

p-ISSN. 2503-0671

e-ISSN. 2548-5547

\section{Pendahuluan}

Pendidikan merupakan suatu ijtihad manusia untuk menuju arah kehidupan yang lebih baik. Hal ini searah dengan Kemendikbud UU. Nomor 20 Tahun 2003 tentang Sistem Pendidikan Nasional pasal 1 ayat pertama yang menyatakan bahwa pendidikan adalah usaha sadar yang terencana dalam menwujudkan suasana belajar dan proses pembelajaran supaya peserta didik secara aktif mengembangkan potensi dirinya untuk memiliki kekuatan spiritual keagamaan, pengendalian diri, kepribadian, kecerdasan, akhlak mulia, serta keterampilan yang diperlukan dirinya, masyarakat, bangsa dan negara. Pendidikan yang baik yaitu pendidikan yang bisa mewarnai kehidupan manusia menjadi lebih baik, berilmu, berakhlak dan mampu memberikan solusi atau pemecahan masalah terhadap masalah yang belum terpecahkan.

Pemerintah Indonesia sangat memperhatikan pendidikan bangsanya yang mana hal itu ditunjukkan dengan adanya peraturan Menteri Pendidikan Nasional terkait pendidikan di Indonesia. Peraturan Mentri Pendidikan Nasional No. 22 tahun 2006 terkait Kurikulum Tingkat Satuan Pendidikan (KTSP) tentang setandar isi, bahwa mata pelajaran matematika untuk semua jenjang pendidikan dasar dan menengah memiliki tujuan supaya peserta didik mampu:

1. Paham terhadap konsep matematika, memberikan penjelasan tentang keterkaitan konsep secara mendalam, akurat, efisien, serta tepat dalam menyelesaikan masalah

2. Mampu menalar dalam pola dan sifat, memanipulasi matematika dalam membuat generalisasi, merangkai bukti, dan memberikan penjelasan gagasan dan pernyataan matematika

3. Mampu Menyelesaikan permasalahan yang berkaitan dengan kemampuan pemahaman masalah, menyusun model matematika, menyelesaikan model, dan menangkap maksud solusi yang diperoleh

4. Mampu mengkomunikasikan gagasan dalam bentuk variabel, tabel, diagram, atau media lain yang dapat memperjelasan permasalahan.

5. Mampu menghargai manfaat kegunaan matematika dalam kehidupan, yaitu memiliki rasa ingin tahu, perhatian, dan minat dalam mempelajari matematika, serta sikap ulet dan percaya diri dalam pemecahan masalah (Choridah, 2013).

Matematika merupakan salah satu mata pelajaran yang paling dipercaya untuk mengasah kemampuan berpikir dan merupakan mata pelajaran alternatif untuk melatih siswa memecahkan masalah. Namun setiap siswa memiliki pemahaman atau reprensentasi berbeda-beda. Representasi merupakan suatu upaya menggambarkan suatu kejadian, pemikiran, dan situasi dalam bentuk simbol, kata-kata, gambar, atau isyarat supaya suatu informasi dapat diterima dengan baik atau sepaham. Menurut NCTM (1989) menerangkan bahwa representasi merupakan salah satu permulaan dari skill komunikasi matematis. Suatu proses pembelajaran yang menitikberatkan pada skill dan kemampuan representasi pada dasarnya melatih skill siswa dalam berkomunikasi. Sedangkan menurut Hutagaol (2013) bahwa representasi matematis yang dimunculkan siswa merupakan ungkapanungkapan dari gagasan atau ide matematika yang ditampilkan siswa dalam upaya untuk memahami suatu konsep matematika atau untuk menemukan solusi dari masalah yang dihadapinya.

Menurut Sabirin (2014) representasi sangat berguna bagi siswa sebagai sarana mengomunikasikan gagasan kepada siswa lain maupun kepada guru. Representasi juga sangat berguna dalam membantu siswa untuk menyelesaikan masalah yang sedang dihadapi dengan lebih mudah. Menurut Rangkuti (2014) representasi merupakan sebuah penyimbolan, pemaknaan, pengungkapan, pelambangan, pemodelan dari gagasan, konsep matematik, dan hubungan di antaranya yang termuat dalam suatu konfigurasi, konstruksi, atau situasi masalah tertentu yang ditampilkan siswa dalam bentuk 
beragam sebagai upaya memperoleh kejelasan makna, menunjukkan pemahamannya, atau mencari solusi dari masalah yang dihadapinya. Representasi berguna sekali terhadap siswa dalam menyelesaikan masalah dengan lebih mudah, juga sebagai sarana mengkomunikasikan gagasan atau ide matematika siswa kepada siswa lain maupun kepada gurunya sendiri (Sabirin, 2014). Cai, Lane, dan Jacabcsin (1996) menyatakan bahwa ragam representasi yang sering digunakan dalam mengkomunikasikan matematika antara lain: tabel, gambar, grafik, pernyataan matematika, teks tertulis, ataupun kombinasi semuanya.

Secara alamiah representasi yang dimiliki setiap siswa berbeda-beda sehingga cara siswa menerima, mengolah, dan memahami informasi juga berbeda. Perbedaan-perbedaan setiap individu yang menentukan cara menerima, mengolah, dan memahami informasi tersebut dikenal dengan gaya kognitif. Menurut Darmono (2013) gaya kognitif adalah cara yang relatif tetap yang dipilih individu terkait dengan menerima, memproses informasi serta memecahkan masalah yang sedang dihadapi.

Gaya belajar merupakan cara mudah bagi individu dalam memperoleh, mengatur, dan mengolah informasi yang diperoleh. Gaya belajar yang sesuai adalah kunci keberhasilan siswa dalam belajar (Ludji Bire, Geradus, \& Bire, 2014). Terdapat tiga tipe dalam gaya belajar yaitu visual, auditorial, dan kinestetik (Deporter \& Hernacki, 2000). Setiap gaya belajar tersebut memiliki definisi tersediri.

Gaya belajar visual adalah gaya belajar yang memanfaatkan penglihatan. Manusia dengan gaya belajar visual akan membayangkan sesuatu yang sedang dibicarakan. Manusia seperti ini memiliki kepekaan yang tinggi terhadap warna, serta mempunyai pemahaman yang cukup terhadap masalah artistik. Namun ciri manusia seperti ini memiliki kelemahan dalam berdialog secara langsung karena terlalu reaktif terhadap suara, sehingga sukar mengikuti arahan secara lisan dan sering salah menginterpretasikan kata atau ucapan (Hamzah, 2008).
Ciri-ciri gaya belajar visual antara lain, 1) berbicara dengan cepat, 2) berpenampilan rapi, 3) tetap fokus meski dalam suasana yang ramai, 4) lebih ingat pada yang dilihat dari pada yang didengar, 5) cenderung membaca dari pada mendengarkan, 6) tekun dan membaca cepat, 7) susah mengungkapkan dengan kata-kata apa yang ada di benaknya, 8) demonstrator, 9) lebih tertarik musik dari pada seni, 10) cepat lupa pada suatu intruksi, kecuali dituliskan, dan meminta untuk diulangi.

Gaya belajar auditorial adalah gaya belajar yang memanfaatkan indera pendengaran untuk meraih kesuksesannya dalam proses belajar. Siswa yang mempunyai gaya belajar auditorial belajarnya lebih cepat dengan memanfaatkan diskusi verbal dan mendengarkan apa yang diucapkan gurunya. Ciri-ciri gaya belajar auditorial antara lain, 1) suka bicara dengan dirinya, 2) berpenampilan rapi, 3) mudah terganggu oleh suasana ramai, 4) dominan belajar dan mengingat apa yang didengar, 5) suka membaca dengan nada tinggi dan mendengar, 6) menggerakkan bibir mereka ketika membaca buku, 7) biasanya fasih dalam berbicara, 8) lebih tepat mengeja dengan keras dari pada menuliskannya, 9) lebih tertarik lelucon lisan dari pada komik, 10) sering bermasalah dengan pekerjaan yang berbau visual, 11) berkata dengan nada yang berpola, 12) pandai dalam menirukan nada, irama, dan suara.

Gaya belajar kinestetik adalah gaya belajar yang lebih mudah memahami pengetahuan dengan bantuan gerakan, sentuhan, dan melakukan. Individu yang bergaya belajar seperti ini sulit untuk berdiam diri berjam-jam karena keinginan untuk beraktivitas dan eksplorasi sangat kuat. Adapun ciri-ciri gaya belajar kinestetik antara lain, 1) bicaranya pelan, 2) berpenampilan rapi, 3) tidak terganggu oleh situasi keributan, 4) belajar dengan memanipulasi dan praktik, 5) melihat dan berjalan memudahkannya dalam menghafal, 6) memanfaatkan jarinya untuk menunjuk ketika membaca, 7) kesulitan dalam menulis tetapi pandai dalam berbicara, 8) menyukai buku-buku dan mereka menggambarkan aksi dengan 
JURNAL GANTANG. April 2019; IV(1): 49 - 59

p-ISSN. 2503-0671

e-ISSN. 2548-5547

gerakan tubuh saat membaca, 9)suka permainan yang menyibukkan, 10) lupa terhadap geografi, kecuali jika memang pernah berada di tempat itu, 11) menggunakan sentuhan untuk mencari perhatian orang lain, 12) menggunakan kata-kata (Endang Astuti \& Resminingsih: 2010).

Setiap siswa memiliki gaya belajar seperti yang telah disebutkan di atas, namun hanya satu gaya yang mendominasi (Ludji Bire et al., 2014). Jarang sekali bahkan tidak ada yang memiliki ketiga-tiganya ada visualnya tinggi yang lainnya rendah, ada yang auditorial tinggi yang lainnya rendah, dan ada kinestetik yang tinggi tapi yang lainnya rendah.

Dalam pembelajaran matematika seringkali ide-ide matematika direpresentasikan dalam bentuk simbol verbal maupun visual. Menurut McEwan \& Reynolds (2007) menyatakan bahwa gaya kognitif yang dimiliki seseorang yang berkaitan dengan kebiasaannya dalam menggunakan alat inderanya dibagi menjadi dua kelompok, yaitu visualizer dan verbalizer. Sedangkan Mayer \& Massa (2003) menyatakan bahwa siswa yang memiliki gaya kognitif visualizer-verbalizer beranggapan bahwa beberapa orang cenderung lebih baik mengolah informasi dalam bentuk kata-kata dan yang lainnya cenderung lebih baik dalam bentukbentuk visual. Perbedaan dua gaya kognitif ini disebabkan oleh kemampuan seseorang dalam mengimajinasikan sesuatu. Kecenderungan siswa yang memiliki kemampuan melihat dalam memperoleh informasi dengan melihat, sehingga memiliki kebiasaan menerima dan mengolah informasi dalam bentuk gambar hal ini merupakan siswa dengan gaya kognitif visualizer. Sedangkan siswa yang memiliki gaya kognitif verbalizer cenderung berkemampuan mendengar, sehingga memiliki kebiasaan menerima dan memperoleh informasi dalam bentuk teks (Ilma, Hamdani, \& Lailiyah, 2017).

$$
\text { Kemampuan matematika siswa }
$$

Indonesia sering diuji diberbagai ajang baik perlombaan maupun evaluasi pembelajaran di sekolah baik yang tingkat sekolah setempat, regional, nasional, dan internasional. Pada kasus ini peneliti mengangkat persoalan representasi matematis siswa bergaya kognitif visualizerverbalizer dalam menyelesaikan soal TIMSS. Trends in International Mathematics and Science Study atau TIMSS merupakan agenda yang dilakukan dalam rangka membandingkan prestasi Matematika dan IPA siswa kelas 8 dan kelas 4 di beberapa negara di dunia dan juga untuk melihat kurikulum yang dicanangkan di setiap negara diimplementasikan. TIMSS diadakan secara rutin setiap empat tahun sekali yang dinisiasi oleh the International Association for the Evaluation of Educational Achievement (IEA). IEA sendiri adalah sebuah organisasi internasional independen yang bekerja sama dengan penelitian internasional dan agensi pemerintahan yang telah menyelenggarakan studi pencapaian antar negara sejak tahun 1959 (Shodiq, 2015).

Capaian TIMSS Indonesia dalam lima periode terakhir kemampuan siswa Indonesia berada di urutan peringkat bawah. Mulai dari periode pertama tahun 1999 Indonesia berada pada urutan ke-34 dari 48 negara, kedua pada tahun 2003 urutan ke-35 dari 46 negara, ketiga tahun 2007 urutan ke-36 dari 49 negara, keempat tahun 2011 urutan ke-36 dari 40 negara, dan kelima tahun 2015 Indonesia hanya mengikutkan siswa kelas IV saja yang sebelumnya tidak pernah diikutkan, pada keesempatan tersebut Indonesia berada pada urutan ke-44 dari 49 negara dengan sekor 397 poin (Rosnawati, 2013).

Berdasarkan pemaparan serta permasalahan di atas maka peneliti berinisiatif untuk mengkaji dan menggali informasi dari berbagai sumber supaya dapat memberikan solusi terhadap permasalahan tersebut. Kemudian peneliti memutuskan untuk mengangkat judul representasi matematis siswa bergaya kognitif visualizer-verbalizer dalam menyelesaikan soal TIMSS sebagai alternatif dari permasalah yang dipaparkan.

\section{Metode Penelitian}

Penelitian ini merupakan penelitian deskriptif dengan pendekatan kualitatif. Data 
yang dibutuhkan dalam penelitian ini dapat menggunakan data kualitatif. Data tersebut bertujuan untuk mendeskripsikan representasi matematis siswa bergaya kognitif visualizerverbalizer dalam menyelesaikan soal TIMSS. Penelitian ini bertempat di SMPN 36 Surabaya kelas VIII C. Subjek dalam penelitian ini adalah empat siswa yang terdiri dari dua subjek bergaya kognitif visualizer rendah dan tinggi. Berikutnya dua subjek lainya bergaya verbalizer rendah dan tinggi.

Peneliti menentukan subjek penelitian berdasarkan tes VVQ (Visualizer and Verbalizer Quection) yang diberikan kepada semua siswa kelas VIII C, tes tersebut bertujuan untuk menggolongkan gaya kognitif siswa. Tes VVQ ini diadopsi dari intrumen yang dikembangkan oleh Richardson (1977) yang terdiri dari 20 penyataan. Setelah pemberian tes VVQ, selanjutnya peneliti memeriksa hasil tes tersebut kemudian memilih dua siswa yang bergaya kognitif visualizer dan dua siswa yang bergaya kognitif verbalizer. Setelah peneliti mendapatkan data siswa yang bergaya kognitif visualizerverbalizer, kemudian peneliti memberikan soal TIMSS yang di adopsi dari soal TIMSS tahun 2011 kepada empat siswa yang telah teruji gaya kognitifnya. Soal-soal tersebut dipilih beberapa yang berkaitan dengan visualizer-verbalizer dengan meminta penilaian pakar.

Pengambilan data berikutnya berupa wawancara. Wawancara tersebut bertujuan untuk memperjelas data yang dikumpulkan melalui tes tulis dengan cara memberikan beberapa pertanyaan langsung kepada siswa yang dijadikan subjek penelitian.

Setelah data tes soal TIMSS \& wawancara sudah terkumpul maka peneliti kemudian melakukan analisis data terkait representasi matematis siswa bergaya kognitif visualizer-verbalizer berdasar pada hasil penyelesaian soal-soal TIMSS dari siswa. Kemudian dari hasil analisis tersebut dapat memberikan gambaran terhadap peneliti terkait representasi matematis siswa sehingga dari gambaran tersebut peneliti dapat memberikan kesimpulan.

\section{Hasil dan Pembahasan}

Hasil dan pembahasan penelitian ini melalui beberapa tahapan, yaitu; ketertarikan terhadap soal yang disajikan untuk mendukung identitas gaya kognitifnya, pemahaman terhadap soal yang merupakan akibat dari kecendrungan gaya kognitifnya, cara menyelesaikan soal yang menggambarkan representasi matematis siswa, dan menentukan hasilnya atua jawabannya sebagai suatu kesimpulan dari representasi matematis siswa.

Subjek bergaya kognitif visualizer tinggi

Hasil penelitian pada subjek bergaya kognitif tinggi yaitu sebagai berikut. Pada soal nomor 1 siswa kurang suka terhadap bentuk penyajian soalnya karena berbentuk soal cerita.

1. Sepotong kayu parjangnya $40 \mathrm{~cm}$. Kayu terscbut dipotong menjadi 3 bagian dengan

satuan cm. Tiga bagian tersebut adalah $2 x-5, x+7$, dan $x+6$. Berapa panjang

potongan kayu terpanjang?

Gambar 1. Soal nomor 1

Gambar 1 merupakan soal nomor 1 yaitu adopsi dari soal TIMSS 2011 bagian aljabar. Pada tahap pemahaman siswa mengaku tidak paham terhadap soal hingga memutuskan untuk bertanya pada penguji yaitu peneliti sebagai penguji. Pada tahap cara penyelesaian siswa menjumlahkan tiga potongan kayu yang berbentuk aljabar .

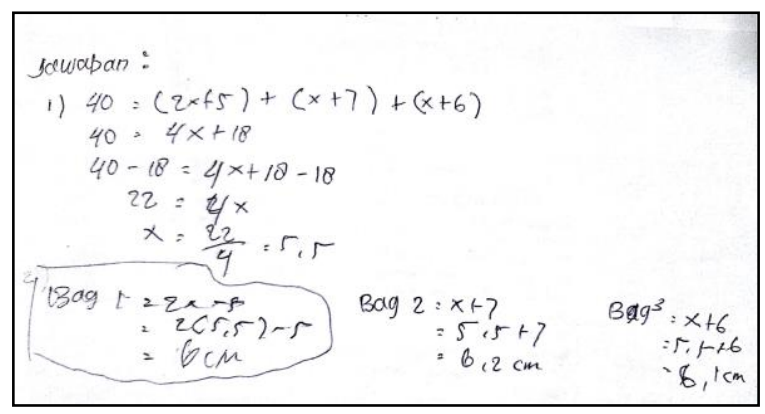

Gambar 2. Respon soal nomor 1

Gambar 2 menunjukkan bahwa siswa menjumlahkan tiga potongan kayunya. Terlihat pada gambar tersebut cara penyelesaian siswa. Namun terdapat kesalahan penulisan tanda penjumlahan tanda minus (-) menjadi tanda plus (+) yaitu pada bagian $2 x-5$ menjadi $2 x+5$ sehingga diperoleh nilai $x=5,5$ dan itu merupakan jawaban yang salah, sedangkan nilai 
JURNAL GANTANG. April 2019; IV(1): 49 - 59

p-ISSN. 2503-0671

e-ISSN. 2548-5547

$x$ yang benar adalah $x=8$. Karena nilai $x$ salah maka hasil setelah disubstitusikan pada setiap bagian potongan juga salah.

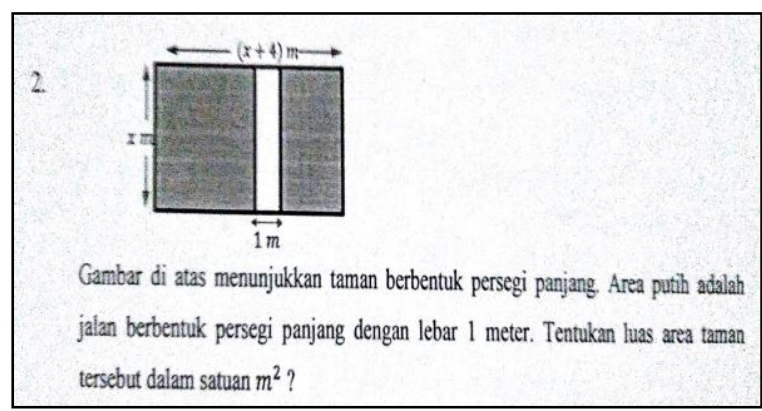

Gambar 3. Soal nomor 2

Gambar 3 merupakan soal nomor 2 yang diadopsi dari soal TIMSS 2011 tentang aljabar. Soal nomor 2 adalah soal aljabar pada bangun datar. Siswa diminta untuk menentukan luas daerah taman atau yang diarsir dimana sisisisinya dalam bentuk variabel.

Pada soal ini siswa yang bergaya kognitif visual tinggi ketika ditanya cukup tertarik dari pada soal yang sebelumnya karena berbentuk gambar. Namun siswa belum bisa menjawab pertanyaan yang diminta yaitu untuk menentukan luas daerah yang sisinya dalam bentuk aljabar sehingga siswa tidak menjawabnya karena memang tidak tahu caranya. Jadi pada soal ini siswa sedikit mengeluh dan bertanya seakan meminta "mengapa sisinya tidak memakai angka saja biar lebih mudah ?" respon verbalnya saat mengerjakan soal tersebut.

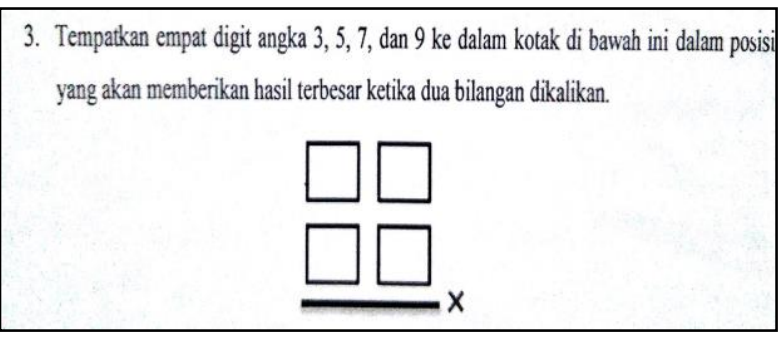

Gambar 4. Soal nomor 4

Gambar 4 merupakan gambar soal yang diadopsi dari soal TIMSS 2011 dalam subbab bilangan. Soal tersebut diterjemah ke bahasa Indonesia. Pada soal ini siswa yang bersangkutan tertarik karena harus mengotak-atik angka hingga menjadi angka terbesar ketika dikalikan.
Jadi pada soal ini siswa diminta untuk memilih secara acak dari empat angka yang disediakan yaitu: 3, 5, 7, dan 9. Angka-angka tersebut diletakkan pada empat kotak yang masing-masing kotak harus terdiri dari satu angka. Syarat peletakan angkanya yaitu ketika sepasang kotak atas dan bawah menghasilkan bilangan sebesar mungkin. Pada tahap pemahaman siswa lebih paham terkait soal setelah dijelaskan oleh penguji. Kamudian pada tahap cara menyelesaikannya siswa melakukan try \& error dangan mengulangi sebanyak tiga kali percobaan seperti terlihat pada gambar 5 .

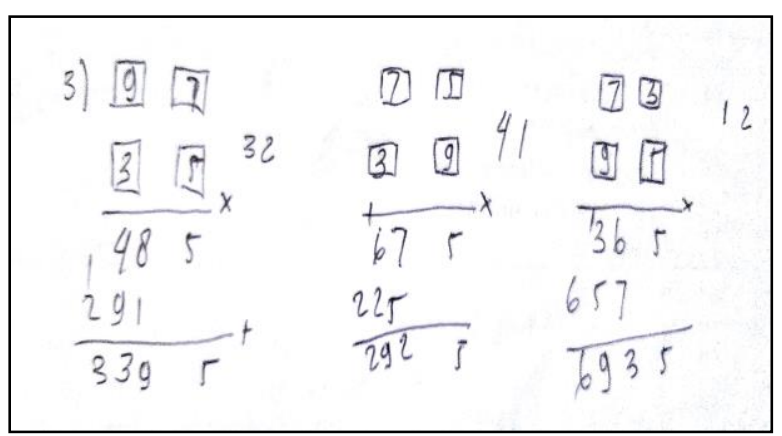

Gambar 5. Respon soal nomor 3

Pada jawaban tersebut siswa hanya melakukan tiga kali percobaan dan berhenti disitu, dia menyakini bahwa hasil jawaban terakhirnya merupakan bilangan terbesarnya. Kenyakinannya karena 95 dan 73 merupakan dua bilangan yang ketika dikalikan dan dijumlah hasilnya lebih besar. Jawaban tersebut kurang tepat karena masih ada bilangan yang lebih besar lagi yaitu 6975 yang merupakan hasil dari perkalian 93 dan 75 .

Subjek bergaya kognitif visualizer rendah

Hasil penelitian pada subjek bergaya kognitif visualizer rendah yaitu pada soal nomor 1 subjek tertarik terhap soalnya karena berbentuk soal cerita. Pada tahap awal siswa suka terhadap bentuk soalnya.

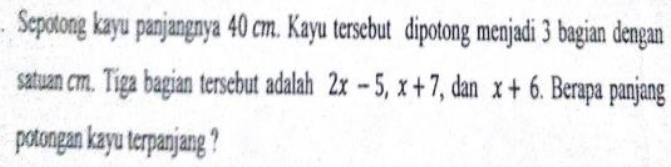

Gambar 6. Soal nomor 1 
Gambar 6 merupakan soal nomor 1 yaitu adopsi dari soal TIMSS 2011 bagian aljabar. Pada tahap berikutnya siswa cukup paham terhadap soalnya namun belum sampai pada finishing, dimana siswa diminta untuk menentukan panjang terbesar potongan kayu. Siswa paham bahwa kayu yang dipotong menjadi tiga bagian yaitu; $2 x-5, x+7$, dan $x+6$. Siswa mencari nilai $x$ dengan cara menjumlahkan tiga potongan tersebut yang berbentuk aljabar disamadengankan dengan 40 . Kemudian diurai hingga ketemu $x=5,5$. siswa mensubstitusikan ke bentuk aljabarnya di masing-masing potongan tersebut.

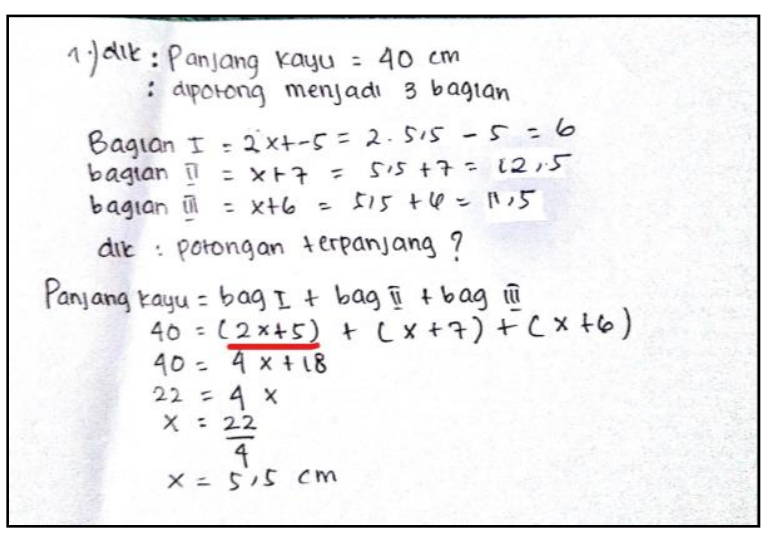

Gambar 7. Respon soal nomor 1

Gambar 7 menunjukkan bahwa pada proses penyelesaian ada kekeliruan yaitu pada uraian yang bergaris merah di atas, sehingga mengakibatkan jawaban akhir salah dimana nilai $x=8$ bukan 5,5. Jadi jawaban nomor 1 salah, kesalahan tersebut bukan karena tidak paham terhadap soal tetapi karena siswa salah dalam menuliskan kembali salah satu persamaan potongan kayu.

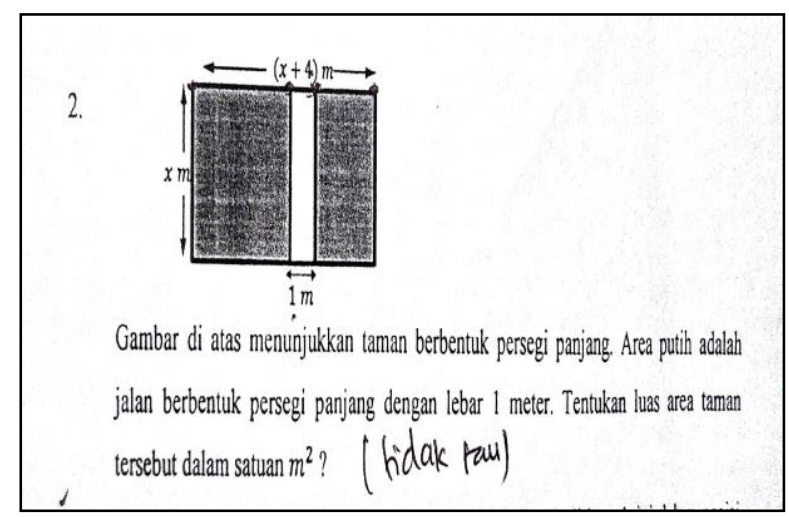

Gambar 8. Soal dan respon nomor 2
Gambar 8 merupakan soal yang nomor 2 yaitu soal yang diadopsi dari soal TIMSS 2011 bagian aljabar bidang bangun datar. Pada tahap ketertarikan, subjek kurang tertarik terhadap soal ini. Kemudian siswa mencoba memahami soal dengan bertanya pada peneliti terkait maksud dari soal tersebut. Setelah diberikan pemahaman terkait maksud soal hingga subjek paham pada soalnya. Kemudian pada tahap penyelesaiannya siswa tidak bisa hingga jawaban terakhirnya "Tidak tahu"

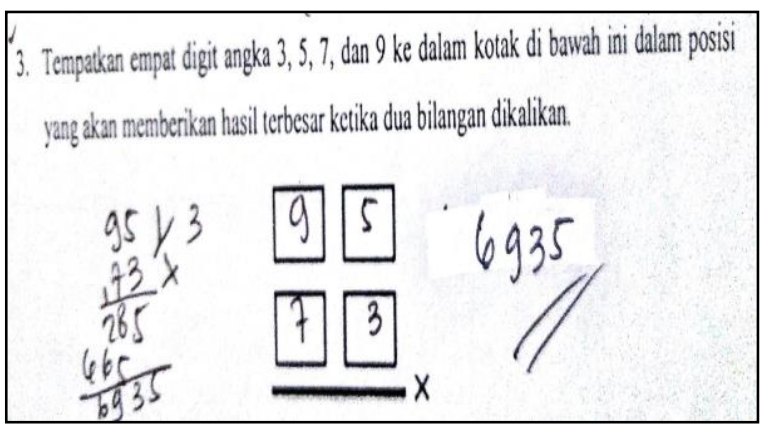

Gambar 9. Soal dan respon nomor 3

Gambar 9 merupakan soal dan jawaban subjek. Pada soal ini siswa paham terhadap soal yaitu; menempatkan empat angka 3, 5, 7, dan 9 pada empat kotak yang sudah disediakan dengan syarat ketika sepasang kotak atas dikalikan dengan sepasang kotak bawah menghasilkan bilangan sebesar mungkin. Pada tahap berikutnya yaitu penyelesaian, ketika ditanya langkah penyelesaiannya siswa menjelaskan bahwa pertama dia memilih angka puluhannya sebesar mungkin yaitu 9 dan 7. Kedua siswa memilih angka satuan dengan memasangkan pada angka puluhan dan menetapkan bahwa angka satuan terbesar dipasangkan dangan angka puluhan terbesar juga dan sebaliknya yaitu 9 dengan 5 dan 7 dengan 3. Kamudian hasil dari perkaliannya adalah 6935 dan itu merupakan jawaban yang kurang tepat karena jawaban yang tepat adalah 6975 didapat dari $93 \times 75$. Jadi pada soal ini siswa menjawab dengan kurang tepat, hal ini disebabkan karena siswa beranggapan bahwa saat 95 dikalikan dengan 73 akan menghasilkan bilangan terbesar karena 95 lebih besar dari 93 tanpa mencoba kemungkinan lain yang justru lebih tepat. 
JURNAL GANTANG. April 2019; IV(1): 49 - 59

p-ISSN. 2503-0671

e-ISSN. 2548-5547

Subjek bergaya kognitif verbalizer tinggi

Hasil penelitian pada subjek yang bergaya kognitif verbalizer tinggi adalah sebagai berikut. Pada soal numor 1 siswa lebih suka karena soalnya berbentuk cerita dan membuatnya berimajinasi atau membayangkan soalnya setelah dibaca. Pada tahap pemahaman siswa dapat memahami soal dengan baik hal itu diketahui saat siswa ditanya terkait pemahamannya. Kemudian siswa mengerjakan soal tersebut dengan terlebih dahulu mencatat informasi yang diketahui. Kemudian siswa menjumlahkan semua tiga potong kayu yang disamadengankan dengan panjang kayu utuh seperti pada gambar 10.

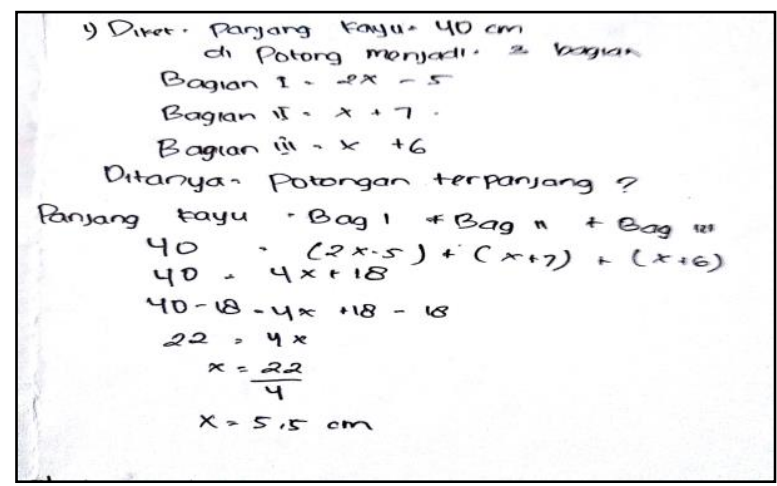

Gambar 10. Respon soal nomor 1

Gambar 10 menunjukkan ada kesalahan siswa dalam proses penjumlahan yaitu saat mencari nilai variabel $x$. Hal itu menyebabkan kesalahan pada tahap selesaiannya sehingga jawabannya salah.

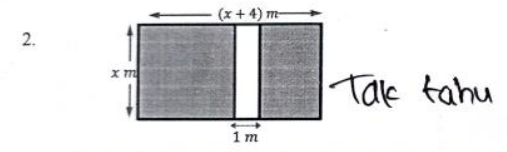

Gambar di atas menunjukkan taman berbentuk persegi panjang. Area putih adalah jalan berbentuk persegi panjang dengan lebar 1 meter. Tentukan luas area taman tersebut dalam satuan $m^{2}$ ?

Gambar 11. Soal dan respon nomor 2

Gambar 11 merupakan soal dan jawan siswa yang bergaya kognitif verbalizer tinggi. Pada soal tersebut siswa tanpa menguraikan apaapa langsung menjawab tidak tahu. Ketidaktahuan itu dapat dipahami oleh peneliti bahwa subjek tidak tertarik terhadap soal, kurang paham terhadap soal dan tidak tahu cara menyelesaikan sehingga jawaban akhirnya langsung diputuskan tidak tahu.

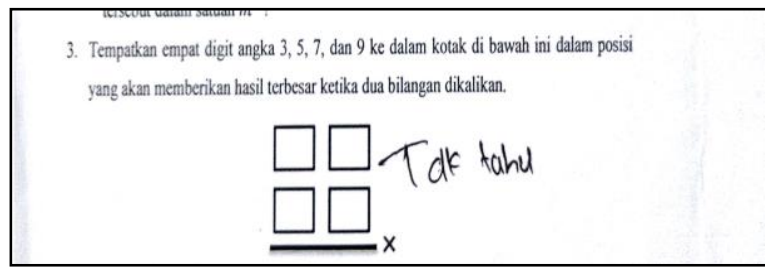

Gambar 12. Soal dan respon nomor 3

Gambar 12 merupakan soal sekaligus jawaban dari siswa. Pada soal ini siswa diminta untuk meletakkan empat angka yang diberikan kedalam empat kotak yang disediakan, kemudian mengkalikannya dengan syarat hasilnya sebesar mungkin.

Adapun respon atau jawaban siswa terhadap soal yang diberikan tidak memberikan jawaban yang dimaksudkan oleh soal. Pada soal ini siswa kurang tertarik terhadap soalnya. Siswan juga tidak paham terhadap soalnya dan tidak tahu cara menyelesaikannya. Sehingga siswa hanya bisa menjawab dengan "Tak tahu"

Subjek bergaya kognitif verbalizer rendah

Hasil penelitian pada subjek yang bergaya kognitif verbalizer rendah adalah sebagai berikut. Pada soal nomor 1 siswa diberikan soal cerita yang diadopsi dari soal TIMSS 2011 tentang aljabar yang telah diterjemahkan ke bahasa Indonesia. Pada soal ini siswa tertarik terhadap soalnya karena berbentuk soal cerita. Kemudian pada tahap pemahaman soal siswa cukup paham dengan apa yang dimaksud dalam soal tersebut, yaitu menentukan potongan kayu terpanjang. Pada tahap berikutnya siswa mencoba menyelesaikan dengan cara menguraikannya terlebih dahulu, dimulai dari mencari nilai $\mathrm{x}$ dengan menjumlahkan semua tiga bagian potongan kayu tersebut yang disamadengankan dengan $40 \mathrm{~cm}$ dalam bentuk persamaan seperti pada gambar 10 . 


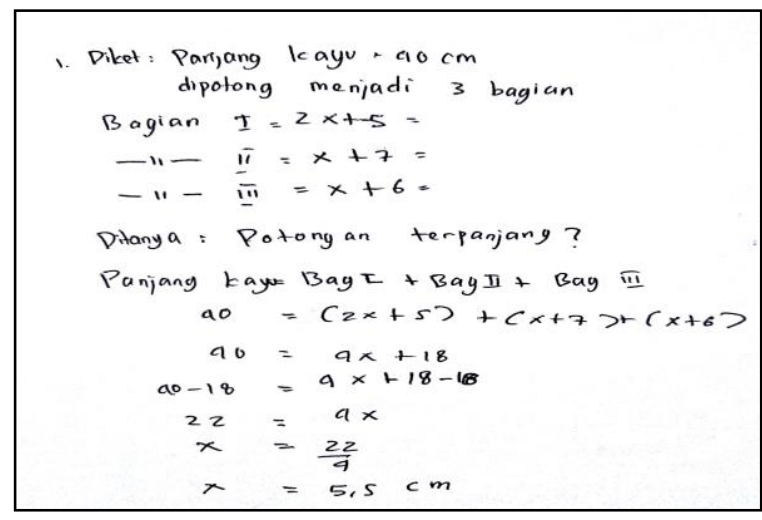

Gambar 13. Respon soal nomor 1

Pada gambar 13 terlihat siswa menguraiakan jawabannya dan terdapat erornya pada penulisan kembali di potongan kayu bagian pertama. Pada bagian tersebut siswa menuliskan ekspansi $2 x+5$ padahal pada soal $2 x-5$, sehingga ketemu nilai $x=5,5$ dan itu salah, seharusnya $x=8$. Hal itu mengakibatkan jawaban akhirnya juga salah.

Pada soal nomor dua siswa diminta untuk menentukan luas daerah taman yang berbentuk persegi panjang dengan satuan $\mathrm{m}^{2}$. Pada tahap ketertarikan soal saat ditanya siswa mengatakan biasa-biasa saja. Pada tahap pemahaman soal, siswa kurang paham terkait maksud dari soal tersebut sehingga memberanikan diri untuk bertanya. Kemudian setelah memahami soal siswa mengerjakannya dengan menggunakan rumus luas persegi panjang.

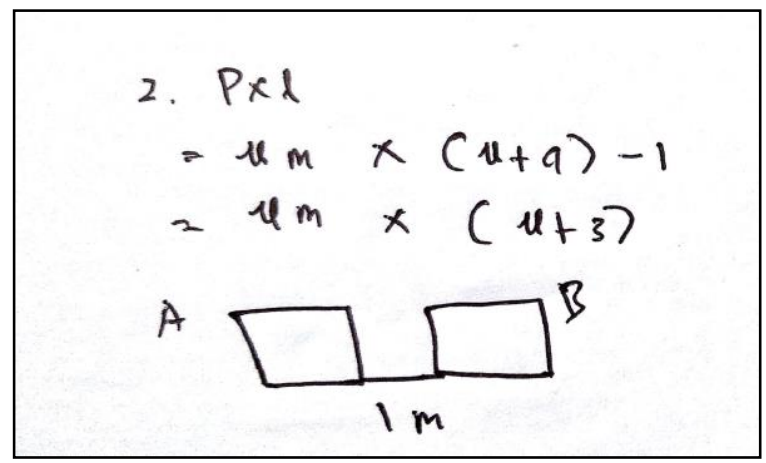

Gambar 14. Respon soal nomor 2

Pada gambar 14 terlihat hasil pengerjaan siswa yang menggunakan rumus luas persegi panjang. Pada sisi panjangnya siswa mengurangi dengan satu karena terdapat jalan yang lebarnya
$1 \mathrm{~cm}$ seperti ilustrasi yang dibuatnya. Cara menyelesaikannya siswa sudah benar, namun belum sampai pada jawaban akhir yang maksud penguji yaitu; $x(x+3) m^{2}$ atau $\left(x^{2}+3 x\right) m^{2}$. Tetapi secara keseluruhan siswa telah benar pengerjaannya.

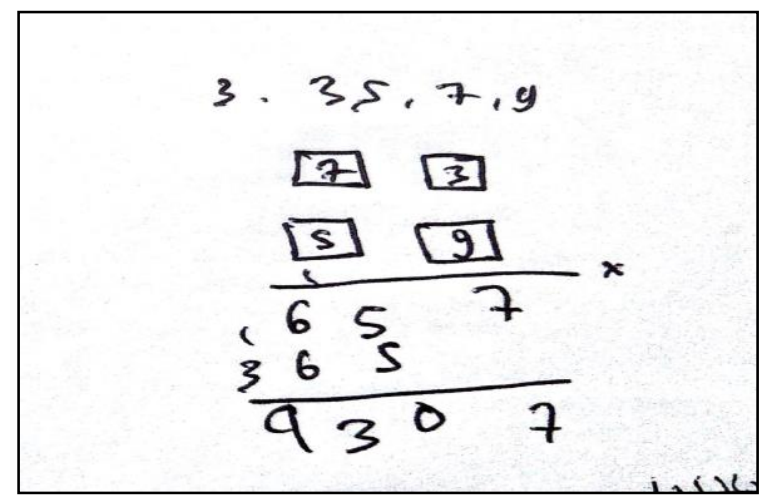

Gambar 15. Respon soal nomor 3

Gambar 15 merupakan jawaban dari soal nomor 3 oleh siswa yang bergaya kognitif verbalizer rendah. Pada soal ini siswa kurang paham pada perintah soalnya. Siswa yang bersangkutan mengira hanya mengisi kotak tersebut dengan angka-angka yang telah disediakan tanpa memperhatikan syaratnya. Pada tahap cara penyelesain siswa langsung mengisi kotak dengan angka-angkanya kemudian mengalikan dan diperoleh hasil seperti gambar 12. Jawaban tersebut tidak seperti yang diharapkan pada soal.

Berdasarkan hasil angket, tes soal, wawancara, dan hasil pengamatan peneliti terhadap subjek, ada beberapa temuan dalam penelitian.

1. Subjek bergaya kognitif visualizer cenderung tertarik pada soal yang disajikan dalam bentuk gambar. Mayoritas siswa yang bergaya tersebut mampu memahami soal yang berbentuk gambar dengan baik dan mampu menguraikannya dengan baik meski tidak sampai pada tahap kesempurnaan atau benarnya jawaban. Sedangkan siswa yang bergaya kognitif verbalizer cenderung susah memahami soalnya dan sulit menguraikannya. Bahkan sering ada siswa yang menjawab soal dengan "Tidak tahu".

2. Subjek bergaya kognitif verbalizer lebih tertarik pada soal yang disajikan dalam 
JURNAL GANTANG. April 2019; IV(1): 49 - 59

p-ISSN. 2503-0671

e-ISSN. 2548-5547

bentuk soal cerita. Siswa yang bergaya tersebut memiliki kecenderungan lebih paham pada soal yang disajikan dalam bentuk cerita. Siswa juga lebih mudah menemukan cara penyelesaiannya.

Hasil penelitian mendukung pernyataan berikut yang menjelaskan bahwa kecenderungan siswa yang memiliki kemampuan melihat dalam memperoleh informasi dengan melihat, sehingga memiliki kebiasaan menerima dan mengolah informasi dalam bentuk gambar hal ini merupakan siswa dengan gaya kognitif visualizer, sedangkan siswa yang memiliki gaya kognitif verbalizer cenderung berkemampuan mendengar, sehingga memiliki kebiasaan menerima dan memperoleh informasi dalam bentuk teks (Ilma, Hamdani, \& Lailiyah, 2017).

\section{Kesimpulan}

Hasil penelitian yang telah dilakukan oleh peneliti terkait Representasi matematis siswa bergaya kognitif visualizer-verbalizer dalam menyelesaikan soal TIMSS dapat disimpulkan bahwa representasi matematis bergaya kognitif visualizer mampu mengerjakan soal yang disajikan dalam bentuk gambar atau ilustrasi dengan baik melalui tahapan-tahapan yang telah ditetapkan oleh peneliti, yaitu; ketertarikan pada soal sesuai gaya kognitifnya, memahami soal lebih ketimbang siswa yang bergaya konitif verbalizer, menggunakan cara penyelesaian lebih baik juga hingga mendekati kesempurnaan pada jawabannya. Sedangkan representasi matematis siswa bergaya kognitif verbalizer mampu mengerjakan soal yang disajikan dengan soal cerita atau narasi lebih mudah memahami serta mampu menguraikan dengan baik serta mampu merepresentasikan dalam bahasa matematika.

\section{Ucapan Terimakasih}

Ucapan terimakasih kepada DRPM DIKTI atas dukungan pendanaannya demi kesuksesan penelitian ini.

\section{Referensi}

Choridah, D. T. (2013). Peran pembelajaran berbasis masalah untuk meningkatkan kemampuan komunikasi dan berpikir kreatif serta disposisi matematis siswa
SMA. Infinity Journal, 2(2), 1-9. https://doi.org/10.1016/j.jclinane.2016.06.0 09

Cai, J., Lane, S., \& Jakabesin, M.S. (1996). The role of open-ended tasks and holistic scoring rubrics: Assessing student's mathematical reasoning and communication. Dalam P.C Elliot \& M.J Kenney (Eds). Yearbook Communication ini Mathematics K-12 and Beyond. Reston, VA: The National Council of Teachers of Mathematics.

Darmono, A. (2013). Identifikasi gaya kognitif peserta didik dalam belajar. Al-Mabsut, $3(1), 63-69$.

Gaylord, J. (1989). National Council of Teachers of Mathematics (NCTM): Curriculum and evaluation standards for school mathematics. Reston, VA: Author.

Hutagaol, K. (2013). Pembelajaran kontekstual untuk meningkatkan kemampuan representasi matematis siswa sekolah menengah pertama. Jurnal Ilmiah, 2(1), 13. https://doi.org/10.1063/1.1853523

Ilma, R., Hamdani, A. S., \& Lailiyah, S. (2017). Profil berpikir analitis masalah aljabar siswa ditinjau dari gaya kognitif visualizer dan verbalizer. Jurnal Review Pembelajaran Matematika, 2(1), 1-14.

Ludji B.A., Geradus, U., \& Bire, J. (2014). Pengaruh gaya belajar visual, auditorial, dan kinestetik terhadap prestasi belajar siswa, 168-174.

Mayer, R. E., \& Massa, L. J. (2003). Three facets of visual and verbal learners: cognitive ability, cognitive style, and learning preference. Journal of Educational Psychology, 95(4), 833-846. https://doi.org/10.1037/0022-0663.95.4.833

McEwan, R. ., \& Reynolds, S. (2007). Verbalisers and visualisers: Cognitive styles that are less than equal. FIRST: Fanshawe Innovation, Research, Scholarship, Teaching, 13.

Rangkuti, A. N. (2014). Representasi matematis. Jurnal Forum Pedagogik, VI(3), 110-127.

Rosnawati, R. (2013). Kemampuan penalaran matematika siswa SMP Indonesia. Prosiding Seminar Nasional Penelitian, Pendidikan Dan Penerapan MIPA, 1-6. https://doi.org/10.4296/cwrj2701043

Sabirin, M. (2014). Representasi dalam pembelajaran matematika. JPM IAIN 
Antasari, $\quad 01(2), \quad 33-44$.

https://doi.org/10.18592/jpm.v1i2.49

Shodiq, L.J. (2015). Seminar nasional matematika dan pendidikan matematika UNY 2015: Analisis soal buku siswa matematika kelas 7 kurikulum 2013 menggunakan TIMSS 2015 mathematics frameworks, 1073-1078. 